\title{
Pelatihan Pengukuran Status Gizi Balita sebagai Upaya Pencegahan Stunting Sejak Dini pada ibu di Dusun Randugunting, Sleman, DIY
}

\section{Toddler Nutrition Status Measurement Training as an Early Prevention of Stunting to Mothers in Dusun Randugunting, Sleman, DIY}

\author{
${ }^{1}$ Khoiriyah Isni, ${ }^{2}$ Siti Muthia Dinni \\ ${ }^{1}$ Fakultas Kesehatan Masyarakat, Universitas Ahmad Dahlan \\ ${ }^{2}$ Fakultas Psikologi, Universitas Ahmad Dahlan \\ Korespondensi : Khoiriyah Isni, khoiriyah.isni@ikm.uad.ac.id
}

Naskah Diterima: 9 Agustus 2019. Disetujui: 21 Januari 2020. Disetujui Publikasi: 25 Januari 2020

\begin{abstract}
Dusun Randugunting has the highest number of toddlers, among other hamlets in the area of Tamanmartani Village, Kalasan, Sleman. It is very risky contributing to the number of cases of stunting if parents pay less attention to children's health and development. The role of parents as the vanguard and take full responsibility for children's health problems, especially nutrition problems for children under five. Parents should have sufficient knowledge and skills to be able to measure the nutritional status of infants by using a simple anthropometric method. The purpose of this training activity is to increase awareness of target skills in early detection of independent stunting by using anthropometric methods. The method of implementing this community service activity uses a combination of education, training, and simulation methods. The targets are pregnant women, mothers with children under the age of five, and health cadres. The results of the implementation of the activity showed quite high enthusiasm from the target. The showed that there were differences in the mean scores before and after the training. It hoped to increase parental awareness on toddler nutrition health problems so that it can have an impact and can contribute to reducing the number of stunting cases in Indonesia.
\end{abstract}

Keywords: Antropometri, stunting, nutrition, randugunting.

\begin{abstract}
Abstrak. Dusun Randugunting memiliki jumlah balita terbanyak diantara Dusun lain di wilayah Desa Tamanmartani, Kalasan, Sleman. Hal ini sangat berisiko menyumbang angka kasus stunting apabila para orang tua kurang memperhatikan kesehatan dan tumbuh kembang anak. Peran orang tua sebagai garda terdepan dan bertanggung jawab penuh terhadap masalah kesehatan anak, terutama masalah gizi balita. Seyogyanya orang tua memiliki pengetahuan dan keterampilan cukup memadai untuk dapat melakukan pengukuran status gizi balita dengan menggunakan metode antropometri sederhana. Tujuan dari kegiatan pelatihan ini adalah meningkatkan kesadaran akan keterampilan sasaran dalam deteksi dini stunting secara mandiri dengan menggunakan metode antropometri. Metode pelaksanaan kegiatan pengabdian ini menggunakan gabungan dari metode edukasi, pelatihan, dan simulasi. Sasarannya adalah ibu hamil, ibu yang memiliki anak usia dibawah lima tahun, dan kader kesehatan. Hasil pelaksanaan kegiatan menunjukkan antusiasme yang cukup tinggi dari sasaran. Harapannya melalui kegiatan ini dapat meningkatkan kesadaran orang tua dalam masalah kesehatan gizi balita, sehingga berdampak dan dapat berkontribusi mengurangi angka kasus stunting di Indonesia.
\end{abstract}

Kata kunci: Antropometri, stunting, gizi, balita, randugunting. 


\section{Pendahuluan}

Masa balita (bawah lima tahun) dan batita (bawah tiga tahun) adalah periode penting dalam proses tumbuh kembang seorang anak. Pertumbuhan dan perkembangan di masa itu menjadi patokan keberhasilan anak di periode selanjutnya. Masa ini tumbuh kembang seorang anak berlangsung sangat cepat dan tidak akan pernah terulang, maka dari itu sering disebut dengan golden age atau masa keemasan. Namun, tantangan pada masa golden age ini adalah kecukupan gizi balita. Apabila balita tidak cukup energy dan gizi, maka sangat rentan mengalami gangguan kesehatan berupa malnutrisi (Utomo \& Anggraini, 2010).

Malnutrisi atau gizi buruk dan kekurangan energi kronis pada seribu hari pertama kehidupan anak dapat menyebabkan gangguan pertumbuhan yang sulit diperbaiki ketika telah dewasa, seperti gangguan kognitif yang dapat mempengaruhi kinerja belajar di sekolah dan ketika bekerja. Anak stunting mengalami gangguan pola makan yaitu selera makan berkurang sehingga pertumbuhan sel otak yang seharusnya berkembang sangat pesat dalam dua tahun pertama kehidupan terhambat (Miller et al., 2015). Hal tersebut berdampak pada pertumbuhan mental dan fisik sehingga potensi anak di masa golden age tidak berkembang dengan maksimal.

Stunting menandakan terjadinya gangguan pertumbuhan yang potensial pada tinggi badan dimana penyebabnya meliputi retardasi pertumbuhan di dalam intrauterine, gizi yang tidak terpenuhi untuk menunjang pertumbuhan dan perkembangan serta penyakit infeksi selama awal kehidupan yang akan mempengaruhi kehidupan mereka selanjutnya (Probosiwi dkk., 2017). Saat ini stunting bukan hanya menjadi masalah kesehatan ditingkat daerah saja, namun sudah menjadi isu kesehatan nasional dan menjadi prioritas masalah kesehatan untuk segera dikendalikan, termasuk di wilayah Kecamatan Kalasan, Kabupaten Sleman, Provinsi Daerah Istimewa Yogyakarta.

Kecamatan Kalasan juga memiliki jumlah bayi terbanyak se-Kabupaten Sleman, sehingga menjadi daerah rawan stunting. Tahun 2016, Kecamatan Kalasan diketahui sebagai daerah dengan angka prevalensi stunting tertinggi di Kabupaten Sleman yaitu 19,82\% (Dinas Kesehatan Kabupaten Sleman, 2017). Kemudian tahun 2017, Kecamatan Kalasan masih termasuk lima besar kecamatan dengan jumlah kasus stunting balita tertinggi di Kabupaten Sleman, selain Kecamatan Minggir, Seyegan, Moyudan, dan Prambanan (Kabupaten Sleman, 2018). Hasil pemantauan status gizi terkait stunting tahun 2017 di Kecamatan Kalasan, sebesar 15,73\% balita termasuk dalam kategori pendek dan sebesar $4,98 \%$ balita termasuk dalam kategori sangat pendek. Sedangkan balita yang termasuk kategori gizi kurang sebesar 7,08\% dan sebesar 0,84\% balita masuk dalam kategori gizi buruk. Masih ditemukan balita dengan status gizi kurus $(6,39 \%)$ dan sangat kurus $(0,06 \%)$. Jumlah bayi berat lahir rendah sebanyak 53 bayi dan 95 bayi lahir pendek. (Dinas Kesehatan Kabupaten Sleman, 2017).

Kejadian stunting hampir merata ditemukan di empat desa wilayah Kecamatan Kalasan salah satunya adalah Desa Tamanmartani. Berdasarkan rekapitulasi Hasil pemantauan status gizi bayi usia 0-59 bulan di Desa Tamanmartani hingga Bulan Maret 2017, angka bayi dengan kasus stunting ditemukan 48 bayi dengan status gizi kurang, sebanyak 31 bayi memiliki status gizi kurus, dan sebanyak 79 bayi termasuk kategori sangat pendek dan 125 bayi masuk dalam kategori pendek (Puskemas Kalasan, 2017). Berdasarkan observasi lapangan yang telah dilakukan oleh Tim pengusul, Dusun Randugunting merupakan dusun yang memiliki jumlah balita terbanyak diantara dusun lain di wilayah Desa Tamanmartani. Tentu saja, hal ini menimbulkan keresahan bagi warganya terutama kader kesehatan dan penyedia layanan kesehatan, sehubungan dengan kesehatan gizi bayi dan balita. 
Permasalahan yang ditemukan dilapangan kaitannya dengan pencegahan stunting, tidak hanya ditemukan dari penyedia layanan kesehatan saja, namun juga dari penerima layanan kesehatan. Masalah yang dihadapi oleh penyedia layananan kesehatan berupa keterbatasan dana untuk menyelenggarakan kegiatan pelatihan secara rutin dan berkala kepada seluruh kader kesehatan di wilayah Desa Tamanmartani. Selama ini, kegiatan pelatihan kader hanya dilakukan setahun sekali dengan pembatasan jumlah peserta untuk setiap desa. Hal ini tentu tidak efektif dalam menunjang keterampilan dan pembaharuan informasi kesehatan gizi balita bagi para kader kesehatan.

Sementara itu, permasalahan yang terjadi pada penerima layanan kesehatan yaitu kader kesehatan adalah masih kesulitannya kader untuk menggugah kesadraan masyarakat terkait pentingnya optimalisasi perkembangan anak di masa golden age. permasalahan yang dihadapi oleh masyarakat umum, khususnya para ibu dan pengasuh yaitu pertama, kurangnya pengetahuan akan pentingnya pemenuhan gizi seimbang bagi bayi di masa golden age dan dan kurangnya kesadaran pengasuh utama untuk melakukan pemantauan gizi bayi. Hasil survei menunjukkan sebagian besar ibu di Dusun Randugunting adalah pekerja sehingga waktunya tidak sesuai dengan penyelenggaraan posyandu. Sedangkan, Ibu cenderung mendelegasikan tugas pengasuhan bayi sepenuhnya kepada nenek atau saudaranya.

Beberapa upaya telah dilakukan oleh Pemerintah termasuk petugas kesehatan guna menekan angka kejadian stunting di Desa Tamanmartani, antara lain revitalisasi posyandu, pelatihan kader setiap setahun sekali, dan melakukan advokasi kepada stakeholder setempat guna mendapatkan dukungan. Namun demikian, upaya tersebut belum membuahkan hasil yang maksimal. Hal ini dapat disebabkan oleh masyarakat merasa hanya menjadi obyek atau sasaran program yang terus menerus diberikan edukasi tanpa diberikan kesempatan menjadi subyek, misalnya dengan diberikan keterampilan. Kemudian, kurangnya kesadaran masyarakat untuk memantau status gizi balita juga menjadi sebab pendukung tingginya angka kasus stunting.

Berdasarkan uraian permasalahan tersebut, maka diperlukan suatu kegiatan atau aktivitas yang bertujuan untuk meningkatkan keterampilan masyarakat dalam deteksi dini kejadian stunting. Masyarakat perlu diberikan pelatihan pengukuran status gizi balita secara mandiri dirumah, salah satunya dengan menggunakan metode antropometri. Pengukuran status gizi secara antropometri ini menggunakan alat sederhana, seperti timbangan dan meterline. Selain itu juga dapat dipantau melalui pertumbuhan berat badan dan tinggi badan sesuai usia bayi. Apabila orang tua dapat melakukan pengukuran status gizi balita dirumah secara mandiri, harapannya dapat menjadi langkah awal pencegahan stunting sejak dini.

\section{Metode Pelaksanaan}

Tempat dan Waktu. Seluruh rangkaian kegiatan ini dilakukan dalam satu kali waktu yaitu hari Minggu tanggal 21 Juli 2019 selama kurang lebih dua jam bertempat di Kediaman Dukuh Randugunting (Gambar 1).

Khalayak Sasaran. Sasaran utama yang hadir dalam kegiatan ini berjumlah 60 peserta, yang terdiri dari ibu hamil, ibu yang memiliki balita, dan kader posyandu Dusun Randugunting, Desa Tamanmartani, Kalasan, Sleman, DIY. Penentuan besar sasaran berdasarkan data kunjungan posyandu Dusun Randugunting setiap bulan.

Metode Pengabdian. Kegiatan pengabdian kepada masyarakat melalui pelatihan pengukuran status gizi balita ini dilakukan oleh Tim Kegiatan Pengabdian Masyarakat yang terdiri dari dua orang dosen UAD yang berasal dari fakultas kesehatan masyarakat dan fakultas psikologi. 


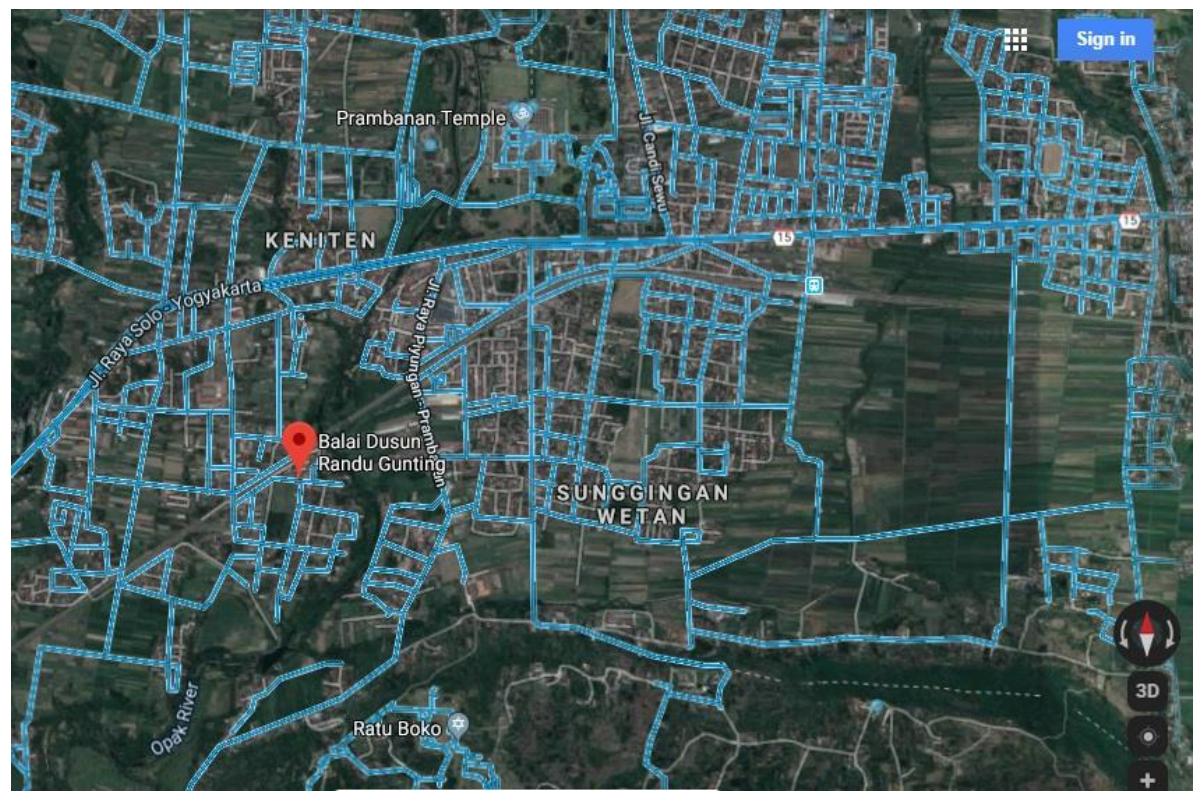

Gambar 1. Peta Lokasi Kegiatan Pengabdian

Kegiatan ini termasuk penelitian tindakan (Action research) yang dilakukan dengan menggunakan 3 metode yaitu :

a. Pendidikan masyarakat atau penyuluhan sebagai upaya mengawali proses pelatihan, bertujuan untuk menghasilkan perubahan sudut pandang peserta terhadap keterampilan dan peran orang tua dalam pengukuran status gizi balita. Materi pendidikan masyarakat atau penyuluhan bermuatan utama terkait gambaran permasalahan gizi di Indonesia, pengertian stunting, dan pengukuran status gizi.

b. Pelatihan atau praktik sebagai upaya lanjutan dalam proses pelatihan, yang bertujuan untuk meningkatkan kecakapan atau keterampilan orang tua sebagai garda terdepan pencegahan stunting sejak dini.

c. Metode simulasi, sebagai upaya akhir mensinergikan antara pengetahuan mengenai keterampilan orang tua dalam mengukur status gizi balita yang diperoleh melalui proses pendidikan masyarakat atau penyuluhan dengan pelatihan atau praktik. Sehingga hasil yang diperoleh lebih maksimal dengan adanya simulasi. Simulasi yang dilakukan meliputi simulasi pengukuran berat badan, tinggi atau panjang badan, lingkar kepala, lingkar dada, dan lingkar lengan atas.

Indikator keberhasilan. Tingkat pengetahuan sasaran menunjukkan adanya peningkatan sebelum dan setelah diberikan pelatihan.

Metode evaluasi. Pengumpulan data dilakukan melalui pengisian angket sebelum dan setelah dilakukannya kegiatan dan dokumentasi kegiatan. Selanjutnya, analisisa data dilakukan dengan pendekatan kuantitatif melalui uji $\mathrm{T}$ berpasangan. Indicator keberhasilan kegiatan dilihat dari jumlah peserta yang hadir lebih dari $50 \%$ dari jumlah undangan dan proses pelaksanaan kegiatan pengabdian.

\section{Hasil dan Pembahasan}

Kegiatan pengabdian ini diikuti oleh ibu hamil, ibu yang memiliki balita, dan kader kesehatan Dusun Randugunting, Desa Tamanmartani, Kalasan, Sleman. Dusun Randugunting dipilih sebagai sasaran lokasi kegiatan pengabdian ini karena lokasi ini memiliki jumlah balita terbanyak diantara semua Dusun di wilayah Desa Tamanmartani, Kalasan. Antusiasme peserta dalam kegiatan ini sangat tinggi, dibuktikan dengan jumlah kehadiran sebanyak 60 peserta dari 90 yang diundang. 
Kegiatan berlangsung dengan lancar, dibuka oleh sambutan dari perwakilan Tim pengusul dan dari Dukuh. Selanjutnya peserta diminta untuk mengisi angket sebelum diberikan materi edukasi yang terdiri dari 15 butir pertanyaan singkat selama kurang lebih 5 menit. Hal ini bertujuan untuk mengetahui tingkat pengetahuan peserta sebelum diberikan materi tentang oleh pengukuran status gizi balita oleh narasumber.

\section{A. Pendidikan Masyarakat atau Penyuluhan}

Peserta diberikan edukasi berupa materi tentang pengukuran status gizi balita. Pemberian materi ini dimaksudkan untuk menunjang pengetahuan peserta terkait stunting dan pengukuran status gizi balita. Adapun materi yang diberikan kepada peserta adalah sebagai berikut (1) Gambaran permasalahan gizi di Indonesia, (2) definisi stunting, (3) Penyebab Stunting, (4) Dampak Stunting, (5) Pencegahan Stunting dengan Pengukuran Status Gizi Balita, (6) Cara pengukuran status gizi balita secara mandiri dirumah (Gambar 2).
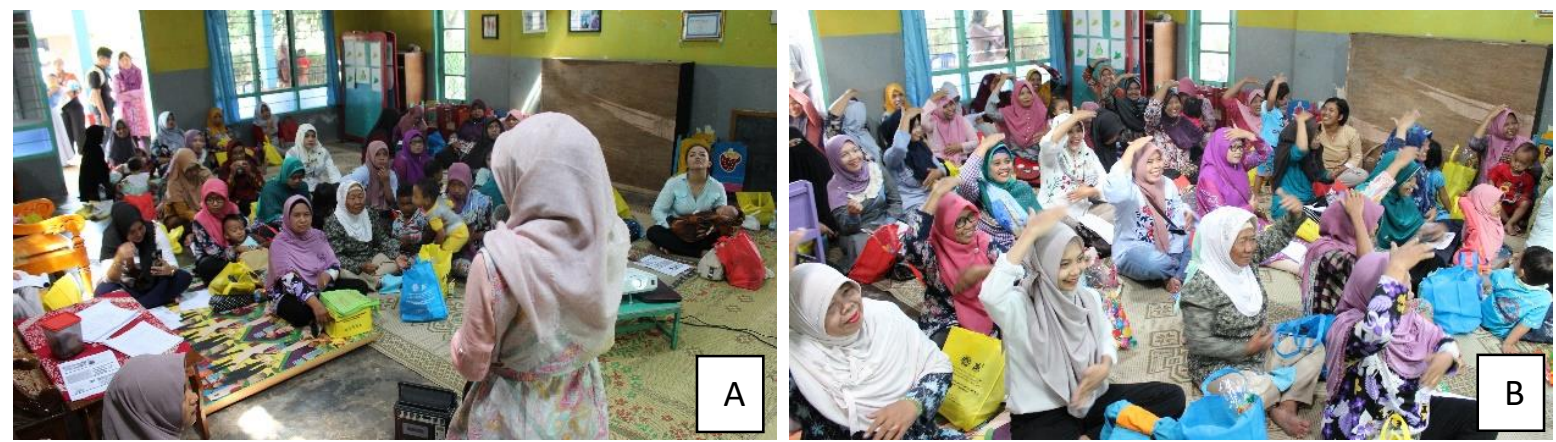

Gambar 2. (A) Pemberian Pendidikan kesehatan atau Penyuluhan; (B) Ice breaking saat pemberian penyuluhan

\section{B. Pelatihan dan Simulasi}

Tahap ini dilakukan setelah diberikan materi edukasi pengukuran status gizi balita. Hal ini dimaksudkan untuk menunjang keterampilan peserta dalam melakukan pengukuran status gizi balita secara mandiri dirumah. Respon dari peserta sangat luar biasa, dibuktikan dengan antusiasme peserta untuk ikut melakukan pengukuran status gizi dengan tepat (Gambar 3).

Kegiatan ini difokuskan pada pengukuran status gizi balita yang tepat dan dapat dilakukan mandiri dirumah dengan peralatan ayng sederhana. Pengukuran status gizi yang dilakukan dengan metode antropometri. Metode antropometri merupakan Pengukuran dimensi tubuh, fungsinya utk mengukur status gizi dari berbagai ketidakseimbangan antara asupan protein dan energi. Kelebihan dari metode antropometri ini adalah alat pengukuran mudah didapat dan digunakan, pengukuran dapat dilakukan berulang-ulang dengan mudah dan objektif, dan dapat dilakukan tidak hanya tenaga khusus professional, serta hasilnya mudah disimpulkan dan diakui kebenarannya secara ilmiah (Supariasa dkk., 2001).

\section{Indikator Keberhasilan dan Evaluasi}

Tujuan dari kegiatan pengabdian ini adalah meningkatkan pengetahuan dan keterampilan peserta. Hal ini diukur melalui angket yang diisi oleh peserta ketika sebelum dan setelah dilakukannya edukasi, pelatihan dan simulasi. Angket berisi 15 pertanyaan singkat mengenai stunting dan cara pengukuran status gizi balita. Kemudian, hasil jawaban dari peserta diolah dan dianalisis secara kuantitatif dengan menggunakan uji $\mathrm{T}$ berpasangan.

Hasil uji T berpasangan disajikan sebagai berikut: 
Table 1. Hasil Uji T Berpasangan ( $\mathrm{N}=39)$

\begin{tabular}{lccccc}
\hline \multirow{2}{*}{ Variabel } & \multirow{2}{*}{ Mean } & \multicolumn{2}{c}{ CI (95\%) } & \multirow{2}{*}{ T hitung } & \multirow{2}{*}{ Sign. } \\
\cline { 3 - 4 } & & Lower & Upper & & \\
\hline $\begin{array}{l}\text { Pengetahuan sebelum dan } \\
\text { setelah pelatihan }\end{array}$ & -5.641 & -9.373 & -1.909 & -3.060 & 0.004 \\
\hline
\end{tabular}

Sumber : Data Primer diolah, 2019.
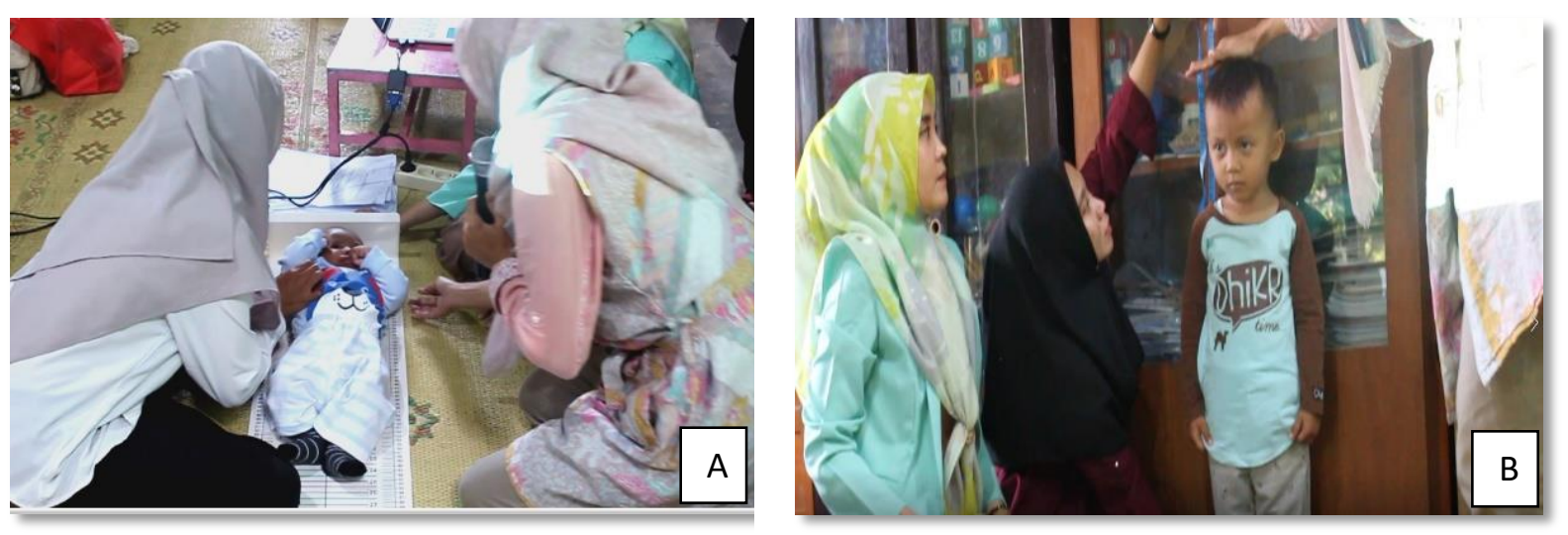

Gambar 3. (A) Pengukuran Panjang Badan Bayi; (B) Pengukuran Tinggi Badan Bayi

Hasil analisis uji berpasangan menunjukkan bahwa terdapat perbedaan rerata antara nilai sebelum diberikan pelatihan dengan setelah diberikan pelatihan (nilai $\mathrm{p}=0,004)$. Kemudian, rerata nilai sebelum diberikan pelatihan lebih rendah dibandingkan dengan rerata nilai setelah diberikan pelatihan (t hitung $=-3.060$ ), sehingga pemberian edukasi, pelatihan, dan simulasi terbukti efektif dalam meningkatkan pengetahuan peserta. Sejalan dengan penelitian yang dilakukan oleh Zaki bahwa hasil evaluasi kegiatan menunjukkan terjadi peningkatan skor pengetahuan dan keterampilan sebelum dan setelah diberikan pelatihan pemantauan status gizi balita pada kader. Peningkatan keterampilan ditunjukkan oleh hampir seluruh peserta dapat dengan benar melakukan penimbangan balita berdiri, pengukuran berat badan bayi kurang dari dua tahun, pengukuran tinggi badan balita, dan pengisian Kartu Menuju Sehat (KMS) (Zaki dkk., 2018). Hasil kegiatan ini juga sejalan dengan kegiatan sosialisasi gizi seimbang dengan sasaran utama yaitu siswa SMA Negeri 15 Makassar, hasilnya menunjukkan bahwa sosialisasi efektif untuk meningkatkan pengetahuan siswa tentang gizi seimbang pada remaja (Kurniati dkk., 2019). Kemudian, peningkatan pengetahuan dan keterampilan melalui kegiatan pelatihan juga ditunjukkan oleh kader kesehatan dalam deteksi dini gangguan gizi. Dampaknya kader kesehatan menunjukkan perbaikan dalam melakukan rujukan gangguan gizi balita dan pendampingan oleh kader berdampak positif bagi layanan kesehatan gizi balita (Kosasih dkk., 2012).

Kesehatan gizi balita merupakan hal yang sangat penting untuk diperhatikan oleh orang tua. Hasil Riskesdas dari tahun 2007 ke tahun 2013 menunjukkan fakta yang memprihatinkan dimana underweight meningkat dari $18,4 \%$ menjadi $19,6 \%$, stunting juga meningkat dari $36,8 \%$ menjadi $37,2 \%$, sementara wasting (kurus) menurun dari 13,6\% menjadi 12,1\% (Kemenkes RI, 2013). Kesehatan gizi yang rendah menyebabkan kondisi daya tahan tubuh menurun, sehingga menyebabkan berbagai penyakit dapat timbul dengan mudah. Seorang anak sehat tidak akan mudah terserang penyakit, termasuk penyakit infeksi yang merupakan penyakit dominan dalam masalah gizi, karena mempunyai daya tahan tubuh yang cukup. Daya tahan tubuh akan meningkat pada keadaan kesehatan gizi yang baik, dan akan menurun bila kondisi kesehatan gizinya menurun (Soetjiningsih \& 
Ranuh, 2014). Harapannya kegiatan pelatihan ini dapat memberikan dampak positif terhadap para orang tua untuk lebih sadar dan waspada serta siaga dalam memantau kesehatan gizi anak.

\section{Kesimpulan}

Kegiatan pelatihan pengukuran status gizi balita telah meningkatkan pengetahuan khalayak sasaran. Peningkatan pengetahuan peserta dan didukung dengan keterampilan peserta melalui metode pelatihan dan simulasi, dapat memberikan kontribusi positif dalam mengurangi dan mencegah kasus stunting di Indonesia, khususnya wilayah Desa Tamanmartani, Kalasan, Sleman, DIY.

\section{Ucapan Terimakasih}

Terimakasih disampaikan kepada Kementerian Riset, Teknologi, dan Pendidikan Tinggi (Kemenristedikti) atas hibah dana yang diberikan melalui Program Pengabdian kepada Masyarakat tahun anggaran 2019 Skim Program Kemitraan Masyarakat (PKM). Selain itu, terimakasih kepada Lembaga Penelitian dan Pengabdian Masyarakat Universitas Ahmad Dahlan (LPPM UAD), seluruh jajaran perangkat Desa Tamanmartani, dan masyarakat Dusun Randugunting yang telah banyak membantu dan ikut berpartisipasi aktif dalam kegiatan ini.

\section{Referensi}

Dinas Kabupaten Sleman. 2017. Rekapitulasi Hasil Pemantauan Status Gizi (PSG) Kabupaten Sleman.

Kabupaten Sleman. 2017. Letak Geografis dan Batas Wilayah Kabupaten Sleman. URL : http://www.slemankab.go.id/profil-kabupaten-sleman/geografi/letakdan-luas-wilayah

Kemenkes RI. (2013). Riset Kesehatan Dasar 2013. In Ministry of Health Republic of Indonesia. https://doi.org/10.1007/s13398-014-0173-7.2

Kosasih, C. E., Isabella, C., \& Sriati, A. (2012). Upaya Peningkatan Gizi Balita Melalui Pelatihan Kader Kesehatan. Jurnal Media Karya Kesehatan, 1(1), 90-100.

Kurniati, Y., Machdar Dachlan, D., Syam, A., Virani, D., Studi Ilmu Gizi Fakultas Kesehatan Masyarakat, P., Studi Kesehatan Masyarakat, P., \& Kedokteran dan Ilmu Kesehatan, F. (2019). Perbaikan Gizi Remaja Berbasis Sekolah Di SMA Negeri 15 Makassar. Jurnal Panrita Abdi, 3(1), 89-96.

Miller, A. C., Murray, M. B., Thomson, D. R., \& Arbour, M. C. (2015). How consistent are associations between stunting and child development? Evidence from a meta-analysis of associations between stunting and multidimensional child development in fi fteen low- and middle-income countries. Public Health Nutrition, 19(8), 1339-1347. https://doi.org/10.1017/S136898001500227X

Probosiwi, H., Huriyati, E., \& Ismail, D. (2017). Stunting dan perkembangan anak usia 12-60 bulan di Kalasan. Journal of Community Medicine and Public Health, 33(11), 1141-1146.

Soetjiningsih, \& Ranuh, G. (2014). Tumbuh Kembang Anak (Edisi Kedua). Penerbit Buku Kedokteran EGC.

Supariasa, I. D. N., Bakri, B., \& Fajar, I. (2001). Penilaian Status Gizi Edisi 2. Jakarta: Penerbit Buku Kedokteran EGC.

Utomo, B., \& Anggraini, D. Y. (2010). Menu Sehat Alami untuk Batita \& Balita. DeMedia.

Zaki, I., Farida, F., \& Sari, H. P. (2018). Peningkatan Kapasitas Kader Posyandu Melalui Pelatihan Pemantauan Status Gizi Balita. Jurnal Pengabdian Kepada Masyarakat (Indonesian Journal of Community Engagement), Vol. 3, pp. 169177. https://doi.org/10.22146/jpkm.28595 
Penulis:

Khoiriyah Isni, Program Studi Kesehatan Masyarakat, Fakultas Kesehatan Masyarakat, Universitad Ahmad Dahlan, Yogyakarta. E-mail: khoiriyah.isni@ikm.uad.ac.id

Siti Muthia Dinni, Fakultas Psikologi, Universitas Ahmad Dahlan, Yogyakarta. Email : s.m.dinni@gmail.com

Bagaimana men-sitasi artikel ini:

Isni, K., \& Dinni, S.M. (2020). Pelatihan Pengukuran Status Gizi Balita sebagai Upaya Pencegahan Stunting Sejak Dini pada ibu di Dusun Randugunting, Sleman, DIY. Jurnal Panrita Abdi, 4(1), 60-68. 
Lampiran: Hasil Analisis Bivariate Uji T berpasangan

Tests of Normality

\begin{tabular}{|l|r|r|r|r|r|r|}
\hline & \multicolumn{3}{|c|}{ Kolmogorov-Smirnov $^{\text {a }}$} & \multicolumn{3}{c|}{ Shapiro-Wilk } \\
\cline { 2 - 7 } & Statistic & \multicolumn{1}{|c|}{$\mathrm{df}$} & Sig. & Statistic & df & Sig. \\
\hline pretest & .118 & 39 & .183 & .963 & 39 & .221 \\
posttest & .154 & 39 & .020 & .956 & 39 & .134 \\
\hline
\end{tabular}

a. Lilliefors Significance Correction

Descriptives

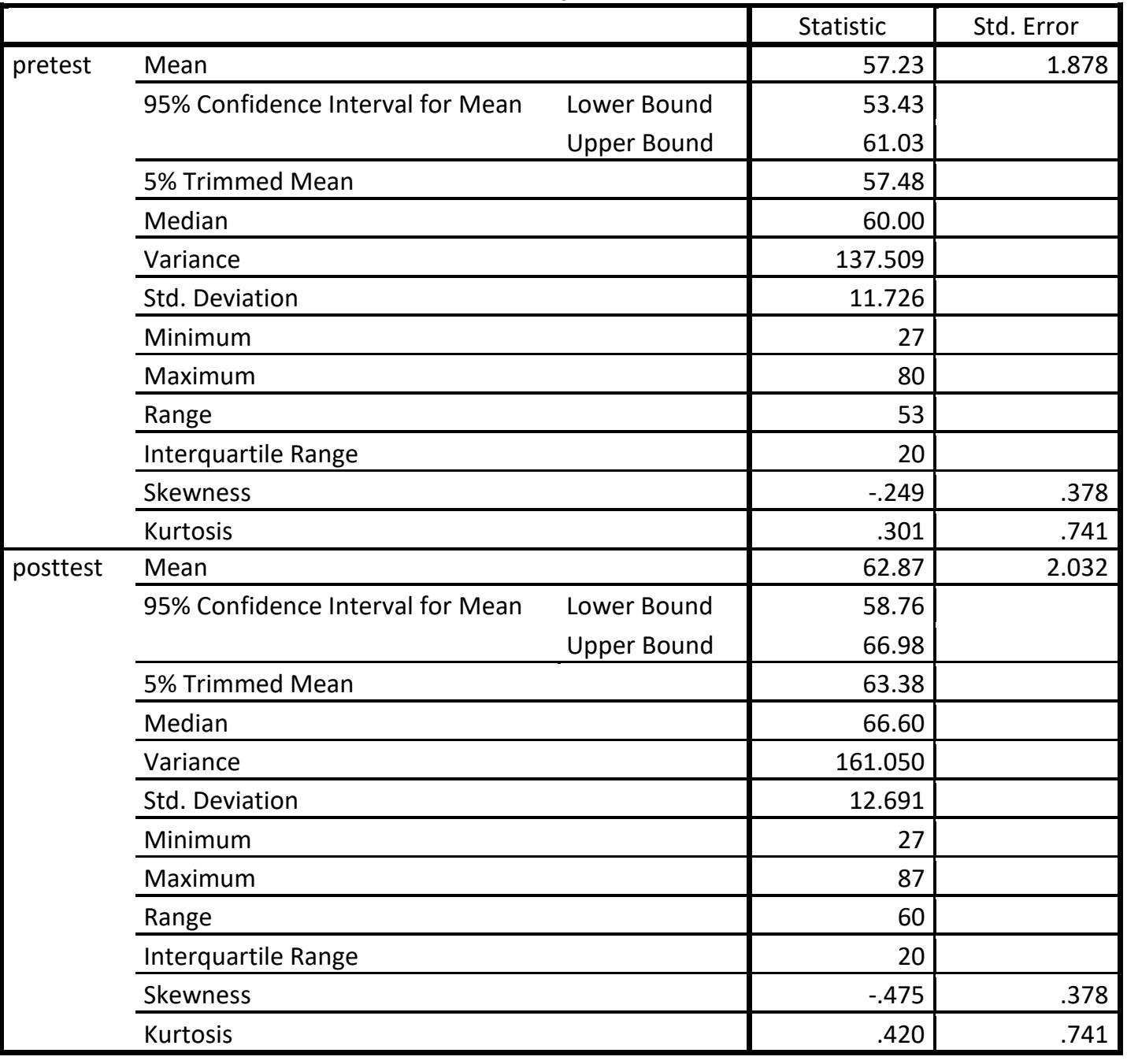

Paired Samples Test

\begin{tabular}{|c|c|c|c|c|c|c|c|c|}
\hline & \multicolumn{5}{|c|}{ Paired Differences } & \multirow[b]{3}{*}{$t$} & \multirow[b]{3}{*}{$d f$} & \multirow[b]{3}{*}{ Sig. (2-tailed) } \\
\hline & \multirow[b]{2}{*}{ Mean } & \multirow[b]{2}{*}{ Std. Deviation } & \multirow[b]{2}{*}{ Std. Error Mean } & \multicolumn{2}{|c|}{$95 \%$ Confidence Interval of the Difference } & & & \\
\hline & & & & Lower & Upper & & & \\
\hline Pair 1 pretest-posttest & -5.641 & 11.512 & 1.843 & -9.373 & -1.909 & -3.060 & 38 & .004 \\
\hline
\end{tabular}

